\title{
Geranium purpureum Vill.: A new casual alien plant in Korea
}

\author{
Hye-Won KIM ${ }^{1}$, Eun-Mi SUN ${ }^{1}$, Su-Young JUNG ${ }^{2}$ and Dong Chan $\mathrm{SON}^{1 *}$ \\ ${ }^{1}$ Korea National Arboretum, Pocheon 11186, Korea \\ ${ }^{2}$ DMZ Botanic Garden, Yangu 24564, Korea \\ (Received 1 September 2019; Revised 16 September 2019; Accepted 24 September 2019)
}

\begin{abstract}
Naturalization centers are hotspots where accidently introduced seeds first germinate and grow. Railways play important roles as corridors for movement, having positive effects on species dispersal and persistence, though they can also be invasion routes for undesirable plants. Geranium purpureum Vill., a new alien species in Korea, was found at the Bumil Railway Station, Busan, Gyeongsangnam-do, Korea. Most native Geranium species in Korea belong to the subgenus Geranium and section Geranium, but G. purpureum belongs to the subgenus Robertium and section Ruberta, with the "carpel-projection" method of seed dispersal. In other countries, G. purpureum is often compared with G. robertianum L., which is an ornamental plant in Korea. We assume that G. purpureum is a casual alien plant and that it is not likely to spread to other provinces, as it scarcely survives when the mean temperature in January is below $4^{\circ} \mathrm{C}$. Moreover, it has not been found further north than Busan. We provide a key of allied taxa, information about the habitat, a description of the morphological characters, illustrations, and photographs.
\end{abstract}

Keywords: unrecorded alien species, Geranium purpureum, Geraniaceae, naturalization center, casual alien plant

Invasive alien species are defined as species that are introduced intentionally or unintentionally and have negative effects on biodiversity (Mooney, 2001). Several other terms related to alien species have also been used by organizations and researchers in Korea (Jung et al., 2017). Recently, Jung et al. (2017) proposed terms by supplementing and standardizing plant-related terms for risk assessment of alien species.

Information about how invasive alien plants invade and spread is important because of their substantial effect on native ecosystems and for their management (Jehlík et al., 2017). In Korea, it is difficult to successfully trace when and how invasive alien plants have entered and spread throughout the country, especially when they spread by cargo, human, or seed contamination (Park, 2009). It is unknown how approximately $67 \%$ of the 309 naturalized plant species in Korea were introduced (Kil and Kim, 2014). This ratio is considerably higher than $30 \%$ in the United States (Mack and Erneberg, 2002), 19\% in South Australia (Kloot, 1987), and 8\% in Nordic Countries (Weidema, 2000).

Naturalization centers are hotspots where accidently introduced seeds first germinate and grow (Park, 2009).
Harbors are one of the main naturalization centers because an array of cargo (including hay, ballast, and packing material) is brought into countries at these points (Park, 2009). Railways also play an important role as naturalization centers and corridors for movement, which have a positive effect on species dispersal and persistence; they can also be an invading route for undesirable plants (Tikka et al., 2001; Jehlík et al., 2013).

Geranium purpureum Vill. was first found in the Bumil Railway Station in Busan, Gyeongsangnam-do, South Korea in 2017. It has also been found in the Busanjin Railway Station ( $2 \mathrm{~km}$ away from the Bumil station) and next to the Busan Harbor. Geranium purpureum is native to eastern and southern Europe, Mediterranean Region, Turkey, Iran, and northern Africa (Tofts, 2004). As an invasive alien species, it has spread throughout north-western Europe, North and South America, Japan, Australia, and New Zealand (Tofts, 2004; Eliáš, 2011). In this paper, we provide a key to the allied taxa, information about habitat and distribution in Korea, a description of the morphological characters, illustrations, and photographs to help manage this potentially invasive alien plant.

\footnotetext{
*Author for correspondence: sdclym@korea.kr
} 


\section{Taxonomic Treatment}

Geranium purpureum Vill., Syst. Pl. Eur. 1: 72, 1786 (Figs. 1, 2)

G. modestum Dum.Cours., Bot. Cult. ed. 2, 5: 29, 1811.

G. minutiflorum Jord., Mém., Acad. Sci. Lyon, Sect. Sci. 1: 250, 1852.

G. mediterraneum Jord., Mém. Acad. Sci. Lyon, Sect. Sci. 1: $251,1852$.

G. villarsianum Jord., Mém. Acad. Sci. Lyon, Sect. Sci. 1: 249, 1852.

G. semiglabrum Jord. ex Boreau, Fl. Centre France ed. 3, 2: 130, 1857.

Robertianum purpureum (Vill.) Fourr., Ann. Soc. Linn. Lyon, n.s., 16: 134, 1868.

G. simile Jord. ex Nyman, Consp. Fl. Eur. 138, 1878.

G. eginense Hausskn. \& Sint. ex R. Knuth, Bot. Jahrb. Syst. 32: 217, 1903.

G. elamellatum Kokwaro, Kew Bull. 23: 527, 1969.

Annual herb (occasionally also reported as biennial), 10-35$\mathrm{cm}$ high, usually branched from the base. Stem decumbent or ascending with glandular hairs, bright or dark green but reddish to red under bright sunlight. One to five extended internodes produced on the main axis with the first flowering branches arising in the upper nodes of this portion and the later ones arising from the lower nodes of the extended stem and upper nodes of the rosette. Stipules ovate, distinct. Leaves opposite, palmate, green and reddish, scattered glandular hairs on both surfaces of the leaves; petioles 2-27-mm long; leaflets 1.58.5-cm long, ovate, deeply pinnatisect, pinnately lobed segments; upper leaves mostly ternate, smaller, on shorter petioles. Pedicels 2-27-mm long, ascending after flowering, mostly straight, pilose. Flowers in pairs (a cymule), but individual flowers sometimes aborted, approximately $7.5 \mathrm{~mm}$ in diameter; sepals 5, 6-8-mm long, ovate, mucronate or shortly aristate with pilose and glandular, erect and somewhat connivent; petals 5, 5-9.5-mm long (including claw), purplishpink; undehisced anthers yellow; pollen yellow; stigma pinkish. Schizocarp 12-24-mm long; mericarps 2.2-3.2-mm long with white silky fiber strands along the edge extending from stigmatic remains, reticulately ridged, with 3-5 pronounced overlapping collars at the apex; rostrum 10-20-mm long with a narrow apex 5-6-mm long. Seeds elliptical-ovate, smooth, light brown, glabrous or hairy, approximately 2-mm long.

Phenology: Flowering and fruiting time March to July.

Vernacular (Korean) name: Yeon-ja-ju-jwi-son-i (연자주 쥐손이; new Korean name).
Habitat and ecology: rocky places, walls, cliffs, hedge banks, railway ballast, dry hills, and disturbed habitats. In Korea, based on field observations, this species was only found in the railway ballast along with Bidens frondosa L., Bidens pilosa L., Chenopodium album L., Commelina communis L., Chrysanthemum indicum L., Ipomoea nil (L.) Roth, Oenothera laciniata Hill, Paederia foetida L., and Taraxacum officinale F. H. Wigg.

Specimens examined: KOREA. Busan: Busanjin-gu, Beomcheon-dong, 26 Apr 2017, Park, S.H.170001 (KH); Busanjin-gu, Beomcheon-dong, 3 Jun 2019, HWK0350 (KH).

Taxonomic note: In Korea, there are 23 native species and two naturalized species of the genus Geranium (Chang et al., 2017). Most native and alien Geranium species in Korea belong to the subgenus Geranium and section Geranium with a seed discharge type of "seed ejection;" however, G. purpureum belongs to the subgenus Robertium and section Ruberta, with a seed discharge type of "carpel-projection" (Aedo et al., 1998) (Fig. 3). In other countries, G. purpureum is often compared with $G$. robertianum $\mathrm{L}$. because it is a closely-related species, and they often grow in the same habitats. However, we can distinguish them easily as the flower of $G$ robertianum is considerably bigger $(15-20 \mathrm{~mm})$ than that of G. purpureum $(7.5 \mathrm{~mm})$. Furthermore, G. purpureum has shorter calyx hairs $(0.5 \mathrm{~mm})$ and a smaller corolla (5-9 mm), whereas, G. robertianum has longer calyx hairs $(0.5-2 \mathrm{~mm})$ and a larger corolla (10-13 mm) (Fig. 4). In Korea, G. robertianum was introduced as an ornamental plant (Korean name: Love-pungrocho, 러브풍로초) and is reported to be naturalized (Jung et al., 2015). Some authorities separate $G$. purpureum into two subspecies, namely, ssp. purpureum and ssp. forsteri (Wilmott) H. G. Baker, based on the different forms of the stem (Baker, 1955). Here, we present the key of Geranium species in Korea, which are alien plants.

\section{Key to Geranium purpureum and its related species in Korea}

1. Seed discharge type seed ejection

2. Petals white or pale pink, anthers yellow, mericarps non-glandular pubescent ………...... G. carolinianum

2. Petals deep pink, anthers purplish yellow, mericarps glandular pubescent …………….......... G. dissectum

1. Seed discharge type carpel projection

3. Hairs on the calyx $0.5-2-\mathrm{mm}$ long; corolla $10-13-\mathrm{mm}$ long; anther color pink, orange, purple, or red; mericarp apex with overlapping weak ridges ……..... G. robertianum

3. Hairs on the calyx $\pm 0.5-\mathrm{mm}$ long, corolla $5-9-\mathrm{mm}$ long, anther color yellow, mericarp apex with pronounced overlapping ridges ……... G. purpureum 

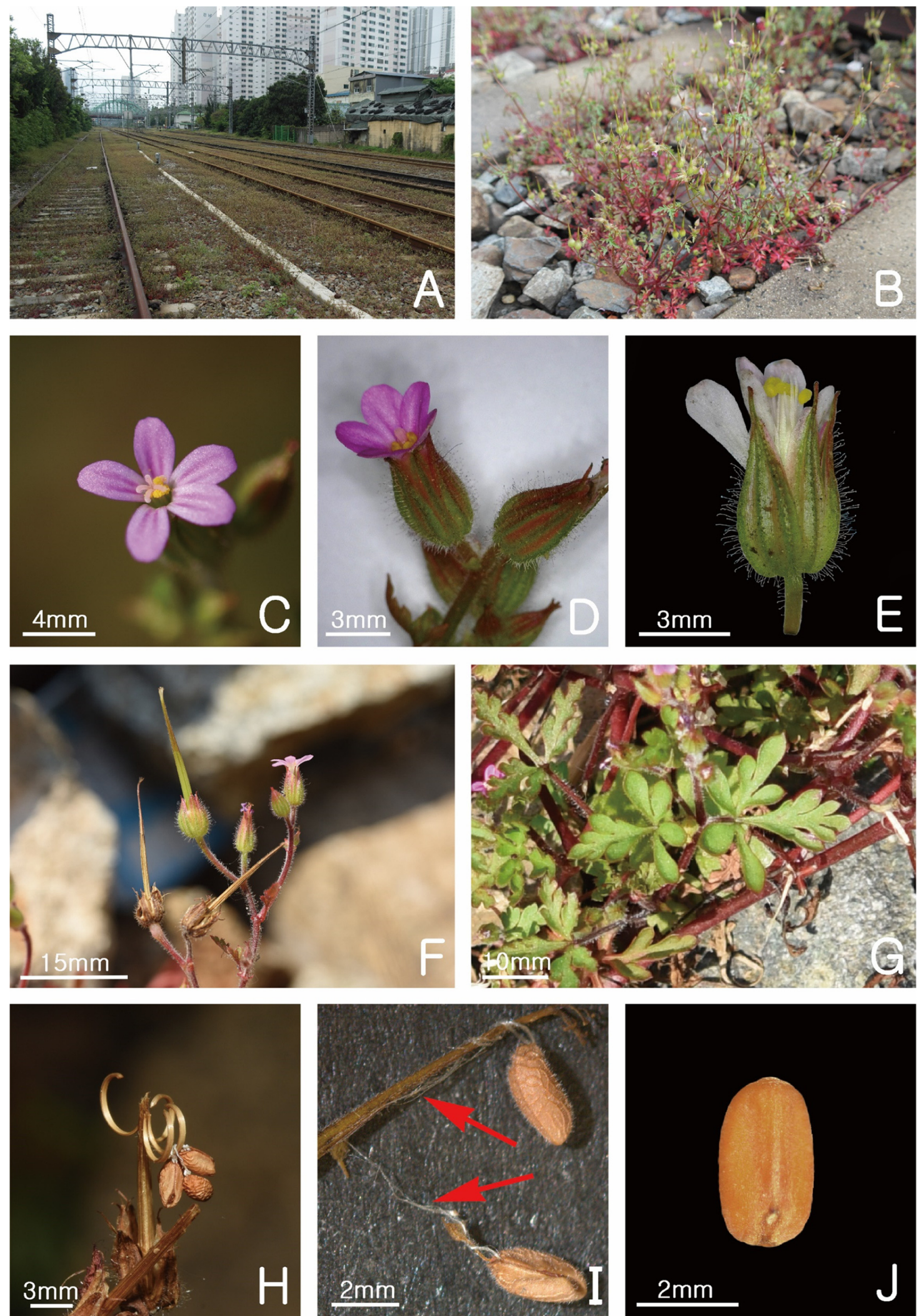

Fig. 1. Photographs of Geranium purpureum Vill. A. Plants in railway lines. B. Habit. C. Flower (top view). D. Inflorescence. E. Sepals. F. Inflorescence. G. Stems and leaves. H. Mericarps with rostrum. I. Mericarps with white silky fiber strands. J. Achene. Photographs by SuYoung Jung, Hyeryun Jo, and Hye-Won Kim. 


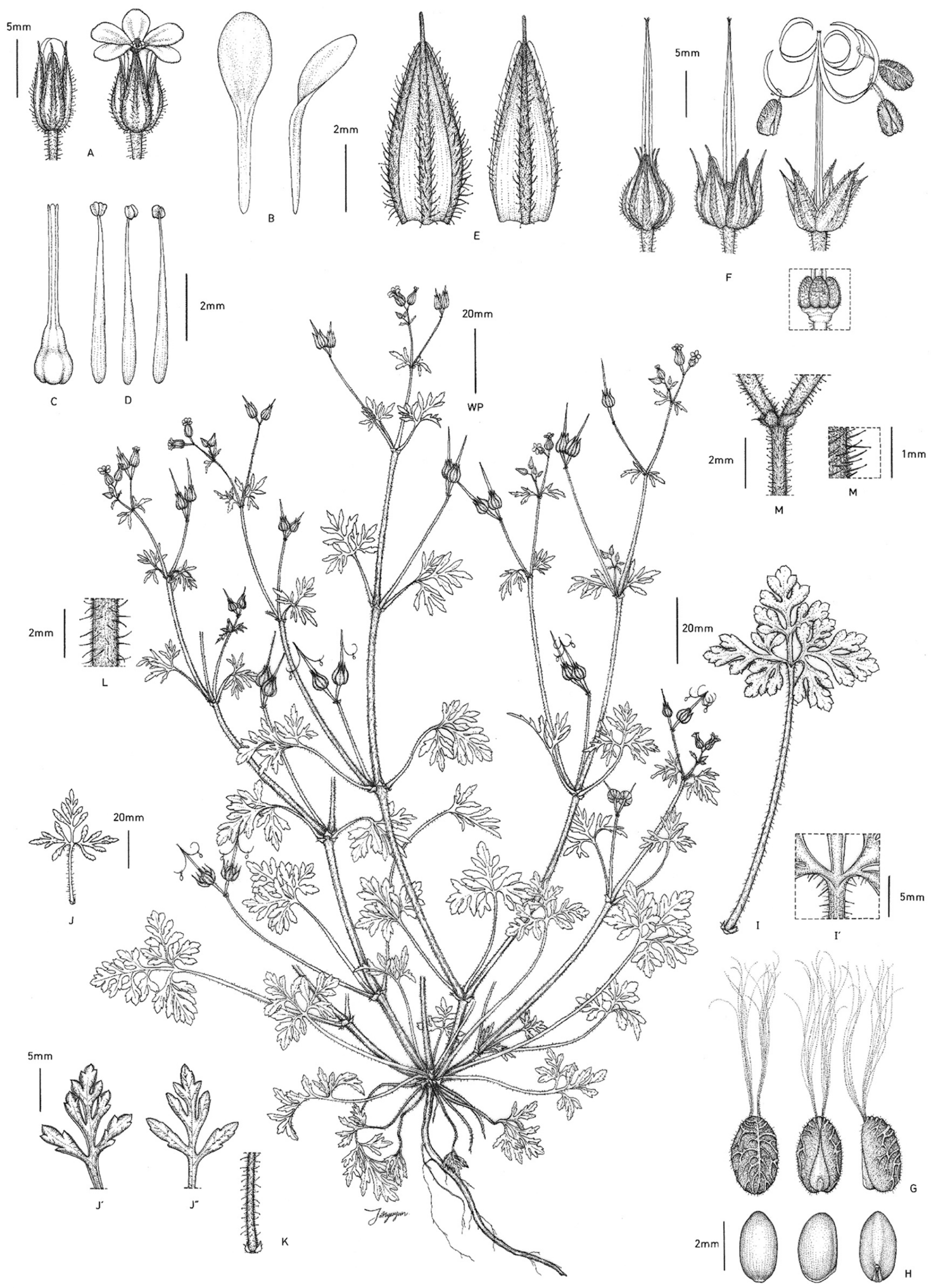

Fig. 2. Illustrations of Geranium purpureum Vill. A. Flower. B. Petal. C. Pistil. D. Stamen. E. Sepal. F. Fruit. G. Mericarps with fiber strands. H. Seeds. I-I'. Radical leaves. J. Cauline leaf (adaxial). J'. Cauline leaf (abaxial). K. Petiole of cauline leaf. L. Stem. M. Pedicel. M'. Glandular hairs on the pedicel. Illustrations by Hyeryun Jo. 

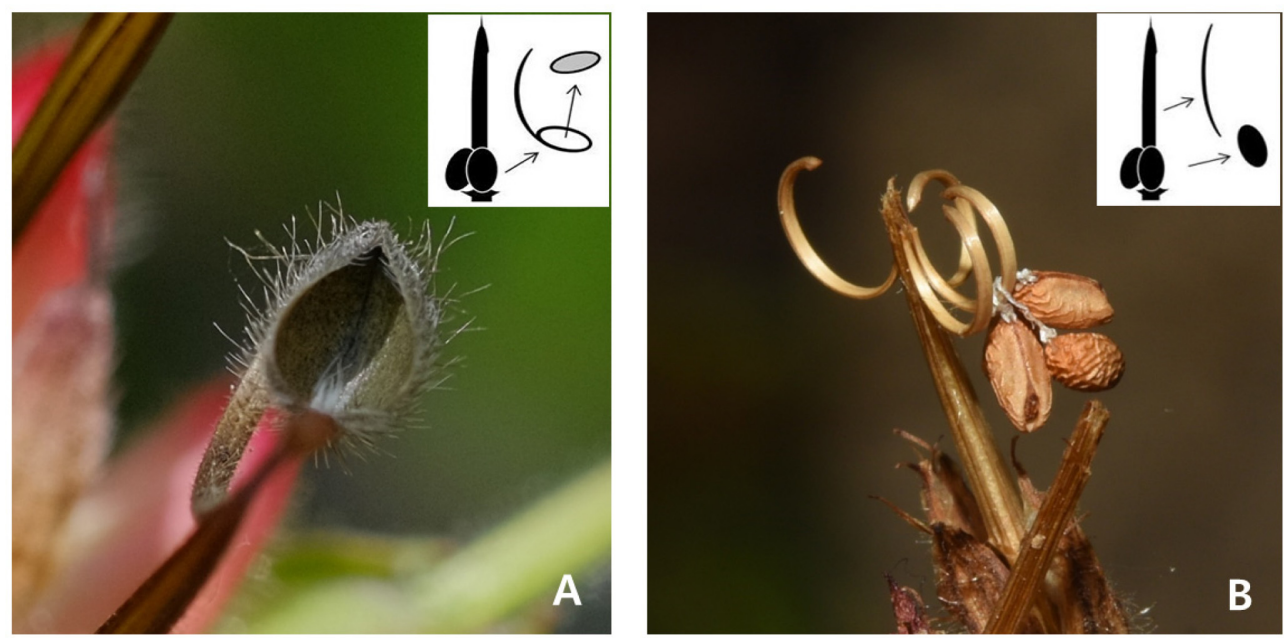

Fig. 3. Type of seed discharge. A. Seed-ejection type of Geranium carolinianum. B. Carpel-projection type of G. purpureum. Photographs by Hye-Won Kim, Illustration by Marcussenand Meseguer (2017).
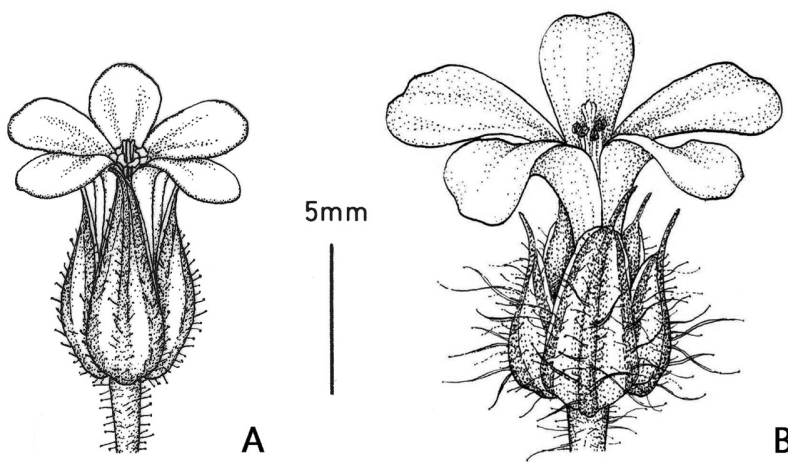

Fig. 4. Size of flowers and hairs on the calyx. A. Geranium purpureum. B. G. robertianum. Illustration by Hyeryun Jo.

\section{Discussion}

It is unusual that G. purpureum was first observed widely at the Bumil Railway Station in 2017. It was not observed in 2018 , but again in 2019 it was widespread at this siteThis pattern of spread provides a clue that there might be some factors with a decisive effect on the survival of $G$. purpureum. We found that G. purpureum is affected by winter temperature. According to Tofts (2004), G. purpureum is restricted to habitats where the mean temperature in January is below $4^{\circ} \mathrm{C}$ and most common where the mean temperature in January is more than $5^{\circ} \mathrm{C}$. In Busan, the mean temperature in January was $4.1^{\circ} \mathrm{C}$ in $2017,1.9^{\circ} \mathrm{C}$ in 2018 , and $4.5^{\circ} \mathrm{C}$ in 2019 (Korea Meteorological Administration, 2019) (Table 1). We surveyed the Ulsan and Gyeongju railway stations as $G$. purpureum has spread along railways, but could not find any plants. The mean temperature in January in both provinces is below $4^{\circ} \mathrm{C}$. Therefore, we assume that $G$. purpureum is currently in the initial stage of naturalization only in restricted areas in Busan and has less possibility of spreading to the northern part of Korea in the later stage of naturalization.

Busanjin station, where we assumed G. purpureum was introduced, is a perfect naturalization center where there is a harbor and a railway. Currently, in Korea, there are no appropriate measures to manage naturalization centers, such as Busanjin. For effective management of invading alien species, more and regular attention should be provided to such hotspots. Not all introduced species become naturalized; only some of them become established and form breeding populations (Mack and Erneberg, 2002). The survival of plants such as $G$.

Table 1. Temperature in January in Busan.

\begin{tabular}{lccccc}
\hline \hline & 2015 & 2016 & 2017 & 2018 & 2019 \\
\hline Lowest temperature in January $\left({ }^{\circ} \mathrm{C}\right)$ & -2.2 & -7.6 & -2.5 & -6.7 & 0 \\
Highest temperature in January $\left({ }^{\circ} \mathrm{C}\right)$ & 10.6 & 11.4 & 9.5 & 9.3 & 8.6 \\
Mean temperature in January $\left({ }^{\circ} \mathrm{C}\right)$ & 4.7 & 3.1 & 4.1 & 1.9 & 4.5 \\
\hline
\end{tabular}


purpureum is limited by temperature in Korea. However, we could ascertain the existence of $G$. robertianum, which was originally planted as an ornamental plant in 2015, growing naturally along the sides of streams in the Ansan Urban Natural Park in Seoul.

Nowadays, several Geranium species have been introduced as ornamental plants. Paying continuous attention to determine whether $G$. purpureum becomes an established species will provide useful information for managing and predicting the future of possible invasive alien species of Geranium and other alien plants that share common life cycle and ecological characteristics.

ORCID: Hye-Won KIM https://orcid.org/0000-0003-31312456; Eun-Mi SUN https://orcid.org/0000-0001-7691-8094; Su Young JUNG https://orcid.org/0000-0002-6755-1072; Dong Chan SON https://orcid.org/0000-0002-6773-0580

\section{Acknowledgements}

We would like to show our gratitude to Seok Min Yun for providing the information regarding the natural habitat for $\mathrm{G}$. purpureum and to Hyeryun Jo for the beautiful illustrations.

\section{Conflict of Interest}

The authors declare that there are no conflicts of interest.

\section{Literature Cited}

Aedo, C., F. M. Garmendia and F. Pando. 1998. World checklist of Geranium L. (Geraniaceae). Anales del Jardín Botánico de Madrid 56: 211-252.

Baker, H. G. 1955. Geranium purpureum Vill. and G. robertianum L. in the British flora. I. Geranium purpureum. Watsonia 3: $160-167$.

Chang, K. S., D. C. Son, D.-H. Lee, K. Choi and S.-H. Oh. 2017. Checklist of Vascular Plants in Korea. Korea National Arboretum, Pocheon, 1000 pp. (in Korean).

Eliáš, P. Jr. 2011. Geranium purpureum Vill.: new alien species to the Slovak flora. Thaiszia Journal of Botany 21: 21-28.

Jehlík, V., J. Májeková and M. Zaliberová. 2013. New discovered adventive plants from eastern Slovakia. Thaiszia Journal of Botany 23: 61-66.

Jehlík, V., M. Zaliberová and J. Májeková. 2017. The influence of the Eastern migration route on the Slovak flora: a comparison after 40 years. Tuexenia 37: 313-332.

Jung, S.-Y., J.-K. Hong, S.-H. Park, J.-C. Yang, S.-M. Yun and Y.S. Kang. 2015. Two unrecorded alien plants of South Korea: Geranium dissectum L. (Geraniaceae) and Dianthus armeria L. Korean Journal of Plant Taxonomy 45: 272-277. (in Korean)

Jung, S. Y., J. W. Lee, H. T. Shin, S. J. Kim, J. B. An, T. I. Heo, J. M. Chung and Y. C. Cho. 2017. Invasive Alien Plants in South Korea. Korea National Arboretum, Pocheon, 265 pp.

Kil, J. and C.-G. Kim. 2014. Current status of naturalization by exotic ornamental plants in Korea. Weed and Turfgrass Science 3: 206-214.

Kloot, P. M. 1987. The naturalised flora of South Australia 3. Its origin, introduction, distribution, growth forms and significance. Journal of the Adelaide Botanic Garden 10: 99-111.

Korea Meteorological Administration. 2019. Retrieved Jul. 26, 2019, available from http://kma.go.kr.

Mack, R. N. and M. Erneberg. 2002. The United States naturalized flora: largely the product of deliberate introductions. Annals of the Missouri Botanical Garden 89: 176-189.

Marcussen, T. and A. S. Meseguer. 2017. Species-level phylogeny, fruit evolution and diversification history of Geranium (Geraniaceae). Molecular Phylogenetics and Evolution 110: 134-149.

Mooney, H. 2001. Invasive alien species-the nature of the problem. In Assessment and Management of Alien Species that Threaten Ecosystems, Habitats and Species. Secretariat of the Convention on Biological Diversity (ed.), Secretariat of the Convention on Biological Diversity, Montreal. Pp. 12-13.

Park, S. H. 2009. New Illustrations and Photographs of Naturalized Plants of Korea. Ilcholkak, Seoul, 575 pp. (in Korean)

Tikka, P. M., H. Högmander and P. S. Koski. 2001. Road and railway verges serve as dispersal corridors for grassland plants. Landscape Ecology 16: 659-666.

Tofts, R. J. 2004. Geranium purpureum Vill. Journal of Ecology 92: 720-731.

Weidema, I. R. 2000. Introduced Species in the Nordic Countries. Nordic Council of Ministers, Copenhagen, 242 pp. 